\title{
Assessment of thermochemical data on steel deoxidation $\left(^{(\bullet)}\right.$
}

\author{
P. Gómez*, F. Reyes*, J. Gutiérrez** and G. Plascencia***
}

\begin{abstract}
It is proposed to develop a method to judge the certainty on the information regarding to deoxidation equilibria of iron melts. To accomplish this objective, thermochemical data was collated and then evaluated. The basic knowledge on deoxidation conditions are framed by the non-ideal Henrian behaviour of diluted solutions of both deoxidizer and oxygen in liquid iron in equilibrium with a pure oxide. Conventional deoxidation reactions were considered at $1,873 \mathrm{~K}$ such that in their equilibrium constants, only first order interaction coefficients were considered. The criteria in selecting the most appropriated free energy equation was based on evaluating them under two critical composition points: 1 where they satisfy an oxygen to deoxidizer ratio dictated by its stoichiometry and 2 where oxygen contents at a given amount of deoxidizer reaches a minimum value. These data were plotted on logarithmic scales to appreciate the effects of deoxidizer's valences. Once such information was classified, under restrictions 1 and 2, previous compositions were related to deoxidizer's electronegativities.
\end{abstract}

\section{Valoración de datos termoquímicos en la desoxidación del acero}

\begin{abstract}
Resumen
El presente artículo propone desarrollar un método para juzgar la certidumbre de la información pertinente al equilibrio de desoxidación de fundidos de hierro. Para lograr este objetivo, se recolectaron y evaluaron datos termoquímicos existentes. Las teorías sobre desoxidación se describen mediante el comportamiento Henriano de soluciones diluidas del agente desoxidante y el hierro fundido en equilibrio con un óxido. En este estudio, solo se consideran reacciones convencionales a $1.873 \mathrm{~K}$, de forma tal que se consideraron las constantes de equilibrio y coeficientes de interacción de primer orden. El criterio empleado para utilizar la expresión más adecuada de la energía libre se basó en evaluar dos puntos críticos: uno, donde se satisface una relación oxígeno/desoxidante dictada por la estequiometría y dos,cuando el contenido de oxígeno alcanza un valor mínimo en presencia de una cantidad predeterminada del desoxidante. Los datos obtenidos se representaron en escalas logarítmicas de forma tal que se pudiese apreciar el efecto de las valencias de los desoxidantes. Con la información así clasificada y bajo las restricciones evaluadas en los puntos críticos uno y dos, las composiciones al equilibrio se relacionan con la electronegatividad del desoxidante.
\end{abstract}

Palabras clave

Acero fundido; Desoxidación; Agentes desoxidantes; Soluciones diluidas; Equilibrio químico.

\section{RATIONALE OF THIS WORK}

Design of mechanical components to satisfy high quality standards demands meticulously controlled processes to such a point where chemical compositions of melts must be satisfied within very narrow limits. This statement becomes yet more valid for steel melts subjected to secondary refining processes such as vacuum ladle metallurgy or electrode remelting processes where assertive compositions are compulsory. These requirements are expected to be met, since the response to further heat treatments, enhance mechanical properties such as fracture toughness or fatigue life among others; which in turn are strongly dependent on the chemical composition and microstructural homogeneity and cleanliness of the resulting metal.

One example of a highly dependent process of chemically restrained stages is that to obtain inclusion shape control by ladle metallurgy. In this process, it

\footnotetext{
(•) Trabajo recibido el día 12 de noviembre de 2008 y aceptado en su forma final el día 20 de febrero de 2009.

* Facultad de Química - UNAM, Dpto. de Ing. Quim. Metalúrgica, Edificio D, México, D.F., C.P. 04510, México.

${ }^{* *}$ ESIME-Azcapotzalco,Av. de las Granjas 682, Col. Sta. Catarina, México, D.F., C.P. 02250, México.

${ }^{* * *}$ CIITEC - IPN,Cerrada Cecati s/n, Col. Sta. Catarina, México, D.F. C.P. 02250, México.
} 
is necessary to reach very low sulphur contents in steel melts and thereafter aluminum additions must be such that melts should reach a fully killed stage; so afterward proceeding with calcium treatment. This sequence of events should be considered as a standard practice in a melt shop to a point such that even if air oxidation prevention fails or if effects of slag accretions on refractories affect oxygen potentials significantly. Henceforth, measures should be at hand to trace, prevent and solve this phenomenon instantaneously. The desired fully killed condition of a melt carried out by aluminum additions as well as the calcium treatment are both very critical in the sense that if they are inappropriate, nozzle clogging must be expected due to precipitation of high melting point phases. Thus, through previous assertions one can establish that despite the fact that previous statements are referred to non equilibrium conditions in these processes; their control should be based on mathematical models which include trustable thermochemical data. Indeed, these postulates become much more meaningful when acute compositions of steel melts demand control to levels of parts per million.

\section{THEORETICAL FRAME OF REFERENCE}

A deoxidation reaction ruled by the Henrian law in mass percent, where solutes are dissolved in pure iron is represented by:

$$
\mathrm{x}[\mathrm{M}]_{1 \% \mathrm{Fe}}+\mathrm{y}[\mathrm{O}]_{1 \% \mathrm{Fe}}=\mathrm{M}_{\mathrm{x}} \mathrm{O}_{\mathrm{y}}
$$
by:

The equilibrium constant for reaction (1) is given

$$
K=\frac{a_{M_{x} O_{y}}}{a_{O}^{y} \cdot a_{M}^{x}}
$$

If deoxidation products are pure, then their activity is unitary, so $\mathrm{K}$ is reduced to:

$$
K=\frac{1}{a_{O}^{y} \cdot a_{M}^{x}}
$$

Additionally, if solutes are infinitely diluted in iron, then a Henrian standard state is given by:

$$
K=\frac{1}{\left[h_{O}\right]^{y} \cdot\left[h_{M}\right]^{x}}
$$

Where, $\mathrm{h}$ is a Henrian activity coefficient. This equation can be expressed as the deoxidation constant $\left(\mathrm{K}^{\prime}\right)$, which is the reciprocal of the former equation, thus

$$
K^{\prime}=\left[h_{O}\right]^{y} \cdot\left[h_{M}\right]^{x}
$$

By taking the logarithm of the previous equation, it can be found a linear relationship:

$$
\log K^{\prime}=y \cdot \log \left(h_{0}\right)+x \cdot \log \left(h_{M}\right)
$$

By assuming real diluted solutions, values of $\mathrm{h}$ can be calculated as follows:

$$
\begin{gathered}
h_{M}=f_{M} \cdot[\% M] \\
h_{O}=f_{O} \cdot[\% O]
\end{gathered}
$$

where, $f$ is commonly referred to as interaction coefficient.

The formal way to represent thermochemical properties of diluted solutions in iron was originally postulated by Wagner ${ }^{[1]}$. Such proposal is based on Mc Laurin series, which are represented by:

$$
\begin{aligned}
& \ln f_{i}=\ln f_{i}^{0}+\sum_{J=2}^{m}\left(\frac{\partial \ln i}{\partial X_{J}}\right)_{X_{F_{e}} \rightarrow 1} X_{J}+\frac{1}{2} \cdot \sum_{J=2}^{m}\left(\frac{\partial^{2} \ln i}{\partial X_{J}^{2}}\right)_{X_{F_{e}} \rightarrow 1} X_{J}^{2}+\ldots \\
& \ldots+\sum_{J=2}^{m-1} \sum_{k \supset J}^{m} \frac{1}{2} \cdot\left(\frac{\partial^{2} \ln i}{\partial X_{J} \cdot \partial X_{k}}\right)_{X_{F_{e}} \rightarrow 1} X_{J} \cdot X_{k}+\ldots
\end{aligned}
$$

As shown in equation (8), the concentration of the species involved in the equilibria are given in mole fractions; however, in practice it is more convenient to express such compositions on a weight percent basis; to do so, we use the following relationship:

$$
[\% i]=100 \frac{X_{i} \cdot M_{i}}{X_{F e} \cdot M_{F e}+\sum_{j=2}^{k} X_{J} \cdot M_{J}}
$$

Substituting back equation (9) into equation (8) yields: 


$$
\begin{aligned}
& \log f_{i}=\sum_{J=2}^{m}\left(\frac{\partial \log i}{\partial \% J}\right)_{\% J \rightarrow 0}[\% J]+\frac{1}{2} \cdot \sum_{J=2}^{m}\left(\frac{\partial^{2} \log i}{\partial \% J^{2}}\right)_{\%\lrcorner \rightarrow 0}[\% J]^{2}+\ldots \\
& \ldots+\sum_{J=2}^{m-1} \sum_{b J\lrcorner}^{m} \frac{1}{2} \cdot\left(\frac{\partial^{2} \log i}{\partial \% J \cdot \partial \% k}\right)_{\% J, \% k \rightarrow 0}[\% J] \cdot[\% k]+\ldots
\end{aligned}
$$

It is interesting to notice that the derivatives in equation (10) represent the so called interaction parameters; and according to the degree of the derivatives, they represent the order of the interaction parameter. Henceforth, by substituting accordingly to such interaction parameters, equation (10) can be represented by:

$$
\log f_{i}=\sum_{J=2}^{m} e_{i}^{J} \cdot[\% J]+\sum_{J=2}^{m} r_{i}^{j} \cdot[\% J]^{2}+\sum_{J=2}^{m-1} \sum_{h, j}^{m} r_{i}^{j, k)} \cdot[\% J] \cdot[\% k]+\ldots
$$

where, $f_{i}$ is the interaction coefficient of the $i$-th element in the melt, $\mathrm{e}_{\mathrm{i}} \mathrm{J}_{\text {is }}$ the first order interaction parameter, $r_{i}{ }^{J}$ is the second order interaction parameter, $r_{i}^{(J, k)}$ is the cross interaction parameter, $\% \mathrm{~J}$ is the deoxidizer in weight percent, \%k is a second solute in weight percent.

In view that the scope of this work is to fundamentally address a method to make an evaluation of the simplest thermochemical data, then Wagner's formalism deduced in equation (11) is reduced to:

$$
\log f_{i}=\sum_{J=2}^{m} e_{i}^{J} \cdot[\% J]
$$

Equation (12) is known as Wagner's truncated formalism. By disclosing equation (12) in terms of a given deoxidizer and oxygen, we obtain the following expressions:

$$
\begin{aligned}
\log f_{M} & =e_{M}^{M} \cdot[\% M]+e_{M}^{O} \cdot[\% O] \\
\log f_{O} & =e_{O}^{O} \cdot[\% O]+e_{O}^{M} \cdot[\% M]
\end{aligned}
$$

where, $\mathrm{M}$ represents a deoxidizer agent.

Therefore, the equilibrium constants for equations (13a) and (13b) are given by:

$$
\begin{aligned}
& \log K= x \cdot\left(\log [\% M]+e_{M}^{M} \cdot[\% M]+e_{M}^{O} \cdot[\% O]\right)+ \\
& y \cdot\left(\log [\% O]+e_{O}^{O} \cdot[\% O]+e_{O}^{M} \cdot[\% M]\right)
\end{aligned}
$$

Provided that previous knowledge on thermochemistry of deoxidation is taken into account, a frame of reference is necessary to establish any point of comparison: (1) The primary point in such referral is that deoxidation (in equilibrium) is carried along to a point where oxygen in solution reaches out the minimum content and (2) the second referral is based primarily on calculating an equilibrium such, that reagents and reaction products strictly satisfy a stoichiometric ratio.

\subsection{Minimum oxygen content}

By considering a starting point, take equation (6) and derive it with respect to the amount of deoxidizer $\mathrm{M}$, thus it follows that:

$$
[O]_{1 \% F e}=f(M)
$$

Therefore, that equation can be expressed as:

$$
\frac{d}{d M}\left(\log K^{\prime}\right)=y \cdot \frac{d}{d M}\left(\log h_{0}\right)+x \cdot \frac{d}{d M}\left(\log h_{M}\right)
$$

where, $\mathrm{x}$ and $\mathrm{y}$ represent the stoichiometric coefficients.

By including the Henrian $1 \mathrm{wt} \%$ standard state in equation (16), it yields:

$$
\frac{d}{d M}\left(\log K^{\prime}\right)=y \cdot \frac{d}{d M}\left(\log \left(f_{0} \cdot \% 0\right)\right)+x \cdot \frac{d}{d M}\left(\log \left(f_{M} \cdot \% M\right)\right)
$$

Applying the properties of logarithms to equation (17) and by using the following definitions: $e_{\circ}^{M}=\frac{d}{d J} \log \left[f_{i}\right], \frac{d[\% O]}{d M}=0$ and $\frac{d M}{d M}=1$ then such equation can be minimized so we obtain:

$$
0=y \cdot e_{O}^{M}+x \cdot\left(e_{M}^{M}+\frac{1}{[\% M] \cdot \log e}\right)
$$

or, its equivalent

$$
-\frac{x}{\lceil \% M\rceil \cdot \log e}=y \cdot e_{O}^{M}+x \cdot e_{M}^{M}
$$

Therefore, if $[\% \mathrm{M}]$ is expressed in terms of $\mathrm{e} \sim 2.718281$, thus log $\mathrm{e} \sim 0.434$, then the expression for the minimum deoxidizer content is given by: 


$$
[\% M]_{\min }=-\frac{0.434 \cdot x}{y \cdot e_{\cap}^{M}+x \cdot e_{M}^{M}}
$$

\subsection{Assessment of the stoichiometric composition}

By using the data shown in tables I to VIII, equilibria were calculated by using equation (14). Then these data was plotted as composition changes of [wt $\% \mathrm{O}]$ vs. [wt $\% \mathrm{M}]$ at a unit activity of deoxidation product. By imposing on such plots the stoichiometric line, a unique composition point will be found as an intersection of both equilibria and stoichiometric lines.

Table I. Thermodynamic data for the $[\mathrm{Al}]$ - [O] equilibrium in iron melts at $1,873 \mathrm{~K}$

Tabla I. Datos termodinámicos para el equilibrio [Al] - [O] en hierro fundido a $1.873 \mathrm{~K}$

\begin{tabular}{lllll}
\hline \multicolumn{1}{c}{$\mathbf{e}_{\mathrm{O}}^{\mathrm{Al}}$} & $\mathbf{e}_{\mathrm{Al}}{ }^{\mathrm{O}}$ & $\mathbf{e}_{\mathrm{Al}}{ }^{\mathrm{Al}}$ & $\log \mathrm{K}$ & Ref. \\
\hline-4.1 & -6.9 & 0.045 & 12.956 & 2 \\
-1.17 & -1.977 & 0.043 & 13.6 & 3 \\
-1.25 & -2.12 & & & 4 \\
-4.09 & -6.904 & 0.043 & 13.597 & 5 \\
-3.847 & -6.596 & 0.0446 & 13.341 & 6 \\
-1.17 & -1.98 & 0.04 & 12.57 & 7 \\
-3.847 & -6.596 & 0.0446 & & 8 \\
-5.54 & -9.346 & 0.045 & 14.01 & 9 \\
& & & 13.106 & 10 \\
-1 & -1.69 & 0.043 & 13.62 & 11 \\
\hline
\end{tabular}

Table II. Thermodynamic data for the [Ca] [O] equilibrium in iron melts at $1,873 \mathrm{~K}$

Tabla II. Datos termodinámicos para el equilibrio [Ca] - $[\mathrm{O}]$ en hierro fundido a $1.873 \mathrm{~K}$

\begin{tabular}{rcccc}
\hline $\mathbf{e}_{\mathrm{O}}{ }^{\mathrm{Ca}}$ & $\mathbf{e}_{\mathrm{Ca}}{ }^{\mathrm{o}}$ & $\mathbf{e}_{\mathrm{Ca}}{ }^{\mathrm{Ca}}$ & $\log \mathrm{K}$ & Ref. \\
\hline-313 & -780 & -0.002 & 9.08 & 12 \\
-310 & -780 & 0.0 & 7.15 & 7 \\
-990 & -2500 & -0.002 & & 8 \\
-3600 & -9000 & -0.002 & 10.2 & 13 \\
-990 & -2500 & -0.002 & 9.08 & 14 \\
-515 & -1290 & -0.00 & 15 \\
-475 & -1190 & -0.002 & 8.26 & 15 \\
\hline
\end{tabular}

Table III. Thermodynamic data for the [Ce][O] equilibria (formation of $\mathrm{Ce}_{2} \mathrm{O}_{3} \& \mathrm{CeO}_{2}$ ) in iron melts at $1,873 \mathrm{~K}$

Tabla III. Datos termodinámicos para el equilibrio [Ce] - [O] (formación of $\mathrm{Ce}_{2} \mathrm{O}_{3} y$ $\mathrm{CeO}_{2}$ ) en hierro fundido a $1.873 \mathrm{~K}$

\begin{tabular}{lllllr}
\hline $\mathbf{e}_{\mathrm{O}}{ }^{\mathrm{Ce}}$ & $\mathbf{e}_{\mathrm{Ce}}{ }^{\mathrm{o}}$ & $\mathbf{e}_{\mathrm{Ce}}{ }^{\mathrm{Ce}}$ & $\begin{array}{c}\log \mathrm{K} \\
\left(\mathrm{Ce}_{2} \mathrm{O}_{3}\right)\end{array}$ & $\begin{array}{l}\log \mathrm{K} \\
\left(\mathrm{CeO}_{2}\right)\end{array}$ & Ref. \\
\hline-0.57 & -5.025 & 0.004 & 16.969 & & 6 \\
-12.1 & 106 & 0.0039 & 17.337 & 9.1 & 16 \\
-0.03 & -0.296 & & & & 17 \\
& & & 18.568 & & 18 \\
& & & 17.027 & & 19 \\
& & & 21.103 & 10.747 & 20 \\
& & & 21.087 & 10.733 & 21 \\
& & & 19.573 & & 22 \\
\hline
\end{tabular}

Table IV. Thermodynamic data for the [Cr] $[\mathrm{O}]$ equilibrium in iron melts at $1,873 \mathrm{~K}$

Tabla IV. Datos termodinámicos para el equilibrio $[\mathrm{Cr}]-[\mathrm{O}]$ en hierro fundido a $1.873 \mathrm{~K}$

\begin{tabular}{|c|c|c|c|c|}
\hline$e_{0}{ }^{C r}$ & $\mathbf{e}_{\mathrm{Cr}}{ }^{0}$ & $\mathbf{e}_{\mathrm{Cr}} \mathrm{Cr}$ & $\log K$ & Ref. \\
\hline-0.055 & -0.189 & 0 & & 23 \\
\hline-0.052 & -0.14 & -0.0003 & 3.963 & 2 \\
\hline \multirow[t]{2}{*}{-0.055} & -0.188 & -0.0003 & & 3 \\
\hline & & -0.00067 & 3.863 & 5 \\
\hline \multirow[t]{4}{*}{-0.0485} & -0.1675 & -0.00069 & 3.863 & 24 \\
\hline & & & 3.767 & 25 \\
\hline & & & 3.152 & 26 \\
\hline & & & 3.969 & 10 \\
\hline-0.0578 & -0.1977 & -0.0003 & & 27 \\
\hline-0.04 & -0.14 & -0.0003 & & 28 \\
\hline
\end{tabular}

Table V. Thermodynamic data for the [La] $[\mathrm{O}]$ equilibrium in iron melts at $1,873 \mathrm{~K}$

Tabla V. Datos termodinámicos para el equilibrio [La] - [O] en hierro fundido a $1.873 \mathrm{~K}$

\begin{tabular}{lllll}
\hline $\mathbf{e}_{\mathrm{O}}{ }^{\mathrm{La}}$ & $\mathbf{e}_{\mathrm{La}}{ }^{\circ}$ & $\mathbf{e}_{\mathrm{La}}{ }^{\mathrm{La}}$ & $\log \mathrm{K}$ & $\mathrm{Ref}$. \\
& & & 21.376 & 18 \\
& & & 18.39 & 19 \\
-5 & -43.44 & & & 28 \\
& & & 22.6457 & 21 \\
& & & 19.026 & 22 \\
\hline
\end{tabular}


Table VI. Thermodynamic data for the $[\mathrm{Mg}]-$ [O] equilibrium in iron melts at $1,873 \mathrm{~K}$

Tabla VI. Datos termodinámicos para el equilibrio $[\mathrm{Mg}]$ - [O] en hierro fundido a 1.873 K

\begin{tabular}{llllr}
\hline $\mathbf{e}_{\mathrm{O}}{ }^{\mathrm{Mg}}$ & $\mathbf{e}_{\mathrm{Mg}}{ }^{\mathrm{O}}$ & $\mathbf{e}_{\mathrm{Mg}}{ }^{\mathrm{Mg}}$ & $\log \mathrm{K}$ & Ref. \\
\hline-370 & -560 & & 7.21 & 2 \\
-300 & -460 & & 7.865 & 29 \\
-280 & -430 & 0 & 6.80 & 7 \\
-190 & -290 & & & 30
\end{tabular}

Table VII. Thermodynamic data for the [Mn] [O] equilibrium in iron melts at $1,873 \mathrm{~K}$

Tabla VII. Datos termodinámicos para el equilibrio [Mn] - [O] en hierro fundido a $1.873 \mathrm{~K}$

\begin{tabular}{|c|c|c|c|c|}
\hline$e_{O}^{M n}$ & $e_{M n}{ }^{0}$ & $\mathbf{e}_{\mathrm{Mn}}^{\mathrm{Mn}}$ & $\log K$ & Ref. \\
\hline-0.021 & -0.083 & 0.0 & 1.274 & 31 \\
\hline-0.021 & -0.083 & 0.0 & & 23 \\
\hline \multirow[t]{2}{*}{-0.05} & -0.182 & & 1.90 & 32 \\
\hline & & -0.0026 & & 5 \\
\hline-0.021 & -0.083 & 0.0 & & 8 \\
\hline-0.0167 & -0.0875 & & 1.606 & 33 \\
\hline \multirow[t]{2}{*}{-0.021} & -0.083 & 0.0 & & 17 \\
\hline & & & 1.284 & 10 \\
\hline-0.02 & -0.083 & 0.0 & & 27 \\
\hline
\end{tabular}

Table VIII. Thermodynamic data for the [Si] $[\mathrm{O}]$ equilibrium in iron melts at $1,873 \mathrm{~K}$

Tabla VIII. Datos termodinámicos para el equilibrio [Si] - [O] en hierro fundido a $1.873 \mathrm{~K}$

\begin{tabular}{llllr}
\hline $\mathbf{e}_{\mathrm{O}}{ }^{\mathrm{Si}}$ & $\mathbf{e}_{\mathrm{Si}}{ }^{\mathrm{O}}$ & $\mathbf{e}_{\mathrm{Si}}{ }^{\mathrm{Si}}$ & $\log \mathrm{K}$ & Ref. \\
\hline-0.066 & -0.119 & 0.103 & 4.676 & 31 \\
-0.066 & -0.119 & 0.103 & & 3 \\
-0.131 & -0.233 & 0.103 & 4.676 & 5 \\
-0.131 & -0.23 & 0.107 & 4.639 & 6 \\
-0.131 & -0.23 & 0.107 & & 8 \\
& & & 4.644 & 10 \\
\hline
\end{tabular}

A second alternative to calculate such point; is by considering that an empirically determined equilibria can be explicitly represented by an expression like:

$$
a[\% M]+b \cdot \log [\% M]+c[\% O]+d \cdot \log [\% O]+k=0(20)
$$

where, $\mathrm{k}=\log \mathrm{K}^{\prime}$

Therefore, one must look for an explicit function, such that $[\mathrm{wt} \% \mathrm{O}]_{1 \mathrm{wt} \% \mathrm{Fe}}=\mathrm{f}[\mathrm{M}]$. This second proposal can be accomplished by using Maple ${ }^{\mathrm{TM}}$ software to transform the equilibria deoxidation reactions such as equation (20) into:

$$
[\% 0]=\exp \left[\frac{-a[\% M] \ln (10)+b \ln [\% M]+d \lambda+k \ln (10)}{d}\right]
$$

where, $\lambda$ represent the following parameter:

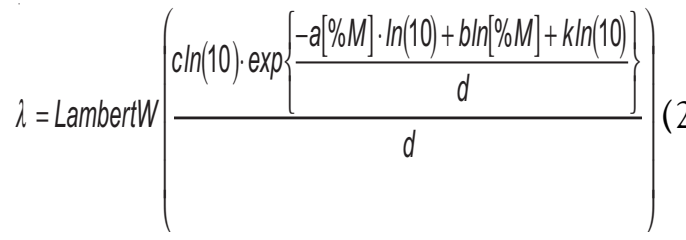

It is important to notice that Lambert's function $\mathrm{W}$ is also known as omega function and it is the inverse of the following function:

$$
f(w)=w \cdot \exp (w)
$$

where, $w$ is a complex variable. However, since the correlations of data regarding thermochemical equilibria are real numbers, then only that part of the solution is considered and the complex part is assumed to be zero.

\section{LITERATURE SURVEY}

Thermochemical data on single deoxidation of iron melts were collected from several sources ${ }^{[2-36]}$. In cases where deoxidizing elements form more than a single solid deoxidation product a single equilibrium was considered for each product along with its own interaction parameters. From all the elements considered, two of them show different oxidation states, namely caesium and titanium. Henceforth, where information about these equilibria was available, it was incorporated to a table as additional columns. 
The Henrian behaviour of infinitely dissolved oxygen and deoxidizer in iron in equilibrium with their oxides with unitary activity are listed in tables I to XI.

Table IX. Thermodynamic data for the [Ti] [O] equilibria (formation of $\mathrm{TiO}_{2}, \mathrm{Ti}_{2} \mathrm{O}_{3} \& \mathrm{Ti}_{3} \mathrm{O}_{5}$ ) in iron melts at $1,873 \mathrm{~K}$

Tabla IX. Datos termodinámicos para el equilibrio [Ti] - [O] (formación of $\mathrm{TiO}_{2} \mathrm{Ti}_{2} \mathrm{O}_{3} \mathrm{y}$ $\mathrm{Ti}_{3} \mathrm{O}_{5}$ ) en hierro fundido a $1.873 \mathrm{~K}$

\begin{tabular}{lllllll}
\hline $\mathrm{e}_{\mathrm{O}}^{\mathrm{Ti}}$ & $\mathrm{e}_{\mathrm{Ti}}{ }^{\circ}$ & $\mathrm{e}_{\mathrm{Ti}}^{\mathrm{Ti}}$ & $\begin{array}{l}\log \mathrm{K} \log \mathrm{K} \log \mathrm{K} \\
\left(\mathrm{TiO}_{2}\right)\end{array}$ & $\left(\mathrm{Ti}_{2} \mathrm{O}_{3}\right)$ & $\left(\mathrm{Ti}_{3} \mathrm{O}_{5}\right)$ & Ref \\
\hline-1.12 & -3.361 & 0.042 & 6.30 & 11.848 & 19.40 & 5 \\
-0.6 & -1.8 & 0.013 & & 11.732 & 6 \\
& & & & 16.102 & 10 & \\
-0.4 & -1.206 & 0.042 & & 11.57 & 18.87 & 11 \\
\hline
\end{tabular}

Table X. Thermodynamic data for the $[\mathrm{V}]-[\mathrm{O}]$ equilibrium in iron melts at $1,873 \mathrm{~K}$

Tabla X. Datos termodinámicos para el equilibrio [V] - [O] en hierro fundido a $1.873 \mathrm{~K}$

\begin{tabular}{lllll}
\hline $\mathbf{e}_{\mathrm{O}}{ }^{\mathrm{V}}$ & $\mathbf{e}_{\mathrm{V}}{ }^{\mathrm{O}}$ & \multicolumn{1}{c}{$\mathbf{e}_{\mathrm{V}}{ }^{\mathrm{V}}$} & $\log \mathrm{K}$ & Ref. \\
\hline & & 5.6383 & 34 & \\
-0.30 & -0.97 & 0.015 & & 17 \\
-0.3 & -0.97 & 0.015 & & 28 \\
-0.12 & -0.39 & 0.02 & 5.885 & 35 \\
\hline
\end{tabular}

Table XI. Thermodynamic data for the $[\mathrm{Zr}]-$ [O] equilibrium in iron melts at $1,873 \mathrm{~K}$

Tabla XI. Datos termodinámicos para el equilibrio $[\mathrm{Zr}]-[\mathrm{O}]$ en hierro fundido a $1.873 \mathrm{~K}$

\begin{tabular}{lcccc}
\hline $\mathbf{e}_{\mathrm{O}}{ }^{\mathrm{Zr}}$ & $\mathbf{e}_{\mathrm{Zr}}{ }^{\mathrm{O}}$ & $\mathbf{e}_{\mathrm{Zr}}{ }^{\mathrm{Zr}}$ & $\log \mathrm{K}$ & Ref. \\
\hline-0.044 & -2.6 & 0.02 & 9.955 & 6 \\
-3 & -17.12 & & & 17 \\
-0.5 & -2.871 & & & \\
-1.0 & -5.721 & 0.032 & 10.28 & 11 \\
-2.0 & -11.42 & & & \\
-0.11 & -0.647 & 0.026 & & 35 \\
\hline
\end{tabular}

\section{RESULTS AND DISCUSSION}

The thermochemistry of iron deoxidation is explored by using several sources of information on deoxidizers, oxygen and deoxidation products in equilibria with iron. Data to carry out this task is considered as a trustful source and these are shown in tables I to XI.

Deoxidation equilibria were calculated by assuming the following: real Henrian behaviour of dissolved species in iron by considering first order interaction parameters, pure oxides or unity activity of deoxidation products and a constant temperature, $1,873 \mathrm{~K}$.

The major variations of deoxidation equilibria are expected to be due to: (i) Change in free energy of formation that will convey to values of $\log \mathrm{K}$ and (ii) magnitude of first order interaction coefficients. Thus variations of type (i) will be identified as a parallelism between two Henrian behaviours where they may be either real or ideal. And, the type (ii) will be traced as the intensity of inflections of non ideal Henrian behaviours. The latter ones are expected to manifest themselves around the minimum oxygen contents and their intensities will be traced as a more pronounced departure from the ideal Henrian behaviour. Therefore, a more negative and higher value of $\mathrm{e}_{\mathrm{O}}{ }^{\mathrm{M}}$ (hence $\mathrm{e}_{\mathrm{M}}{ }^{\mathrm{O}}$ ) would render curlier oxygen-deoxidizer distributions.

It is important to mention that to appreciate those effects in a given deoxidation equilibrium; the deoxidizing agent as well as the oxygen content are both plotted on logarithmic scales. These results are shown in figures 1-12. Subsequently, deoxidation equilibria are solely represented by the critical composition of ratios found where the stoichiometry

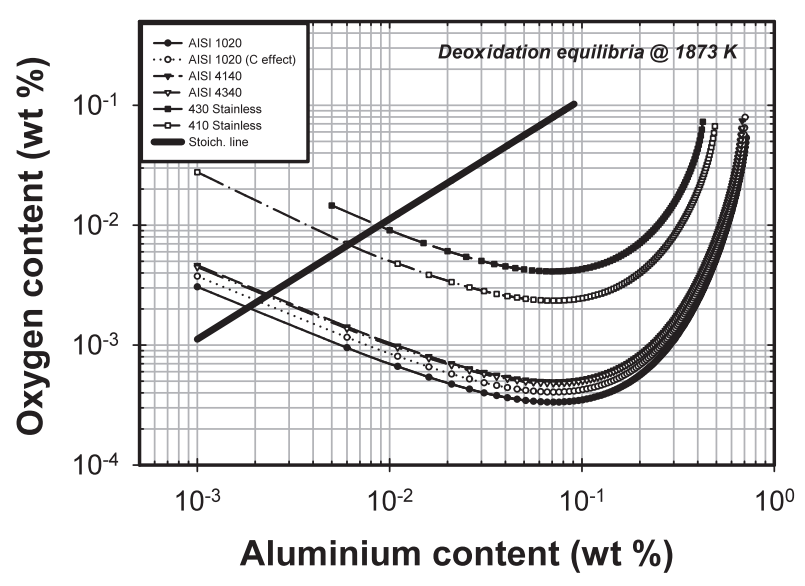

Figure 1. Deoxidation with aluminium on different steel melts at $1,873 \mathrm{~K}$.

Figura 1. Desoxidación con aluminio en diferentes aceros a $1.873 \mathrm{~K}$ 
TECHNICAL NOTE. ASSESSMENT OF THERMOCHEMICAL DATA ON STEEL DEOXIDATION NOTA TÉCNICA. VALORACIÓN DE DATOS TERMOQUÍMICOS EN LA DESOXIDACIÓN DEL ACERO

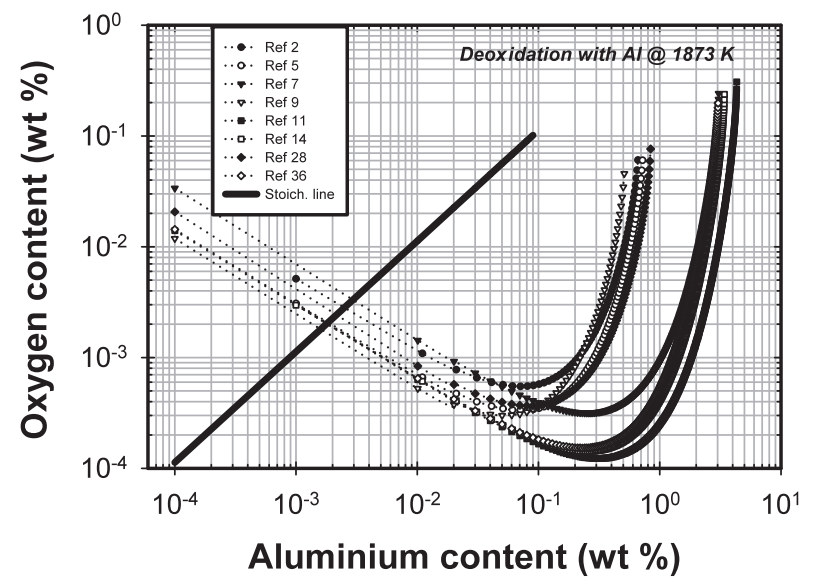

Figure 2. Comparison of equilibria data on steel deoxidation with aluminium at $1,873 \mathrm{~K}$.

Figura 2. Comparativo de los datos al equilibrio al desoxidar acero con aluminio a $1.873 \mathrm{~K}$.

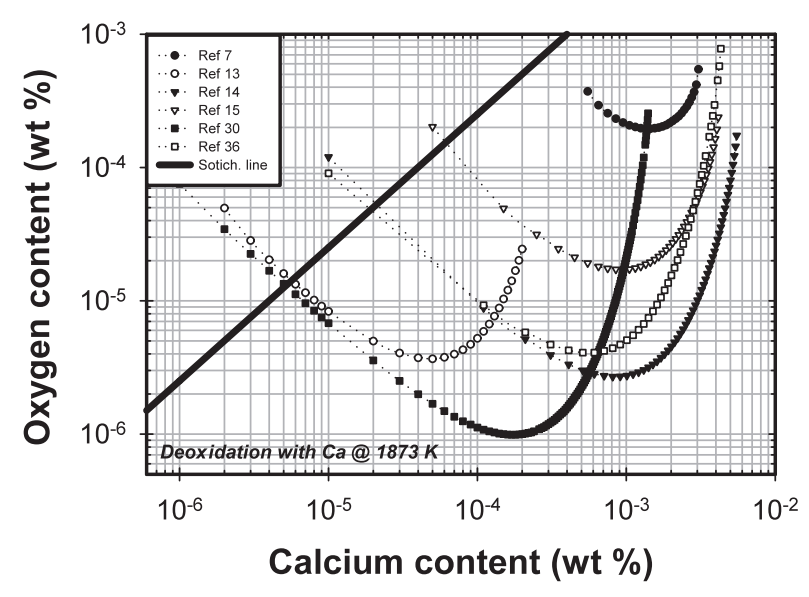

Figure 3. Comparison of equilibria data on steel deoxidation with calcium at $1,873 \mathrm{~K}$.

Figura 3. Comparativo de los datos al equilibrio al desoxidar acero con calcio a $1.873 \mathrm{~K}$.

is satisfied and where the lowest oxygen content is evaluated. However, it must be established that these ratios do not represent a linear composition between them, instead as shown in figure 1 , which corresponds to aluminium deoxidation, for several steel melts, minima composition ratios as described earlier are located around the major inflection of the curve.

Thus, while figure 1 shows effects of several activity coefficients which corresponds to various steel melts, figure 2 shows data from table I that includes several values for $\log \mathrm{K}$ as well as different values for interaction coefficients. It is interesting to note that in both figure 1 and figure 2, composition ratios related to stoichiometric points are less

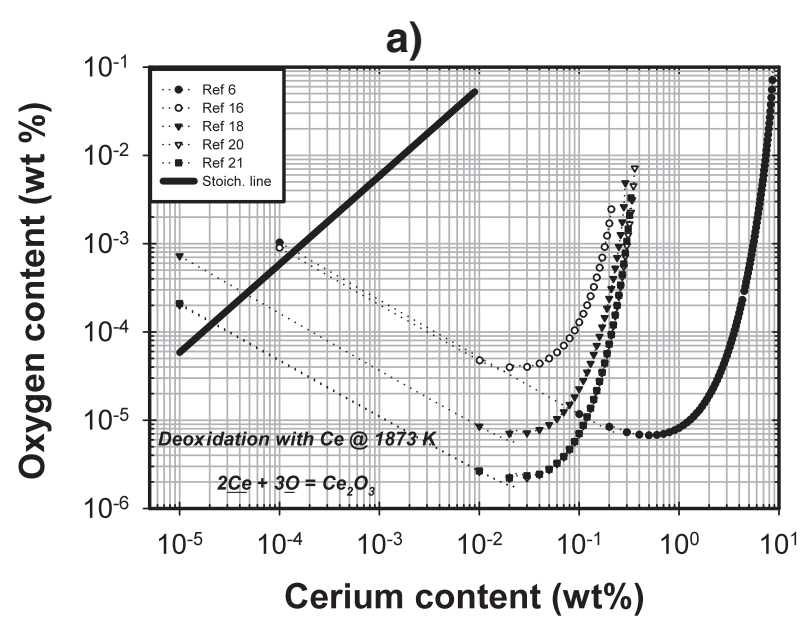

b)

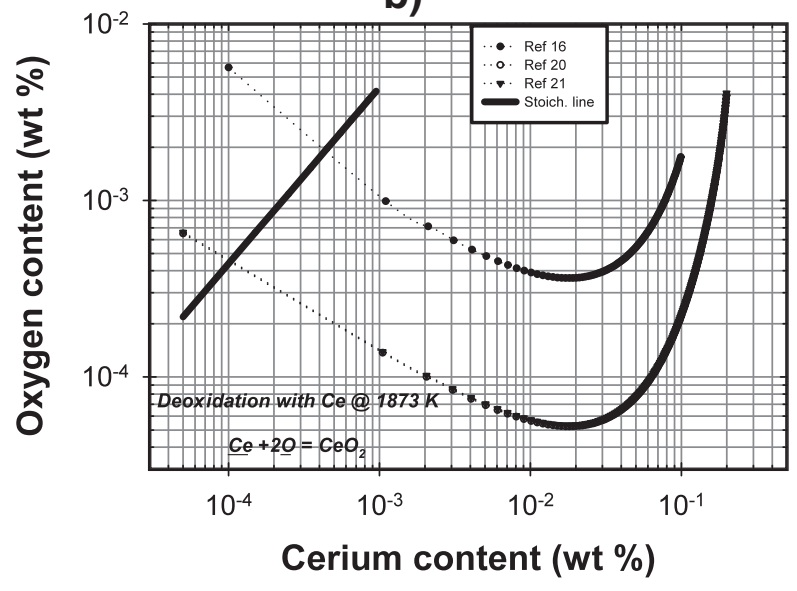

Figure 4. Comparison of equilibria data on steel deoxidation with cerium at $1,873 \mathrm{~K}$. (a) formation of $\mathrm{Ce}_{2} \mathrm{O}_{3}$. (b) formation of $\mathrm{CeO}_{2}$.

Figura 4. Comparativo de los datos al equilibrio al desoxidar acero con cerio a $1.873 \mathrm{~K}$. (a) formación de $\mathrm{Ce}_{2} \mathrm{O}_{3}$. (b) formación de $\mathrm{CeO}_{2}$.

dispersed than those representing the minima oxygen contents. At first sight, deoxidation equilibria shown in figures 2 to 12 can be categorized according to their degree of dispersion. Then, three major groups can comprise the following deoxidizing agents can be identified, namely: 1) $\mathrm{Ca}, \mathrm{Mg}, 2) \mathrm{Al}, \mathrm{Zr}, \mathrm{Si}, \mathrm{Mn}$ and 3) Cr, V, Ti and La.

As a first estimation as to why data shows such inconsistencies, may be attributable to: (1) accuracy of chemical assays in respect to indexes of detection of certain species. Under this premise, one can appreciate that tracing calcium and magnesium in equilibrium with oxygen, all of them infinitely dissolved in iron, it is technically more difficult than tracing chromium or vanadium where equilibria contents are much higher in melts. (2) Incongruities related to basic equilibria data such as $\log (\mathrm{K})$ and 


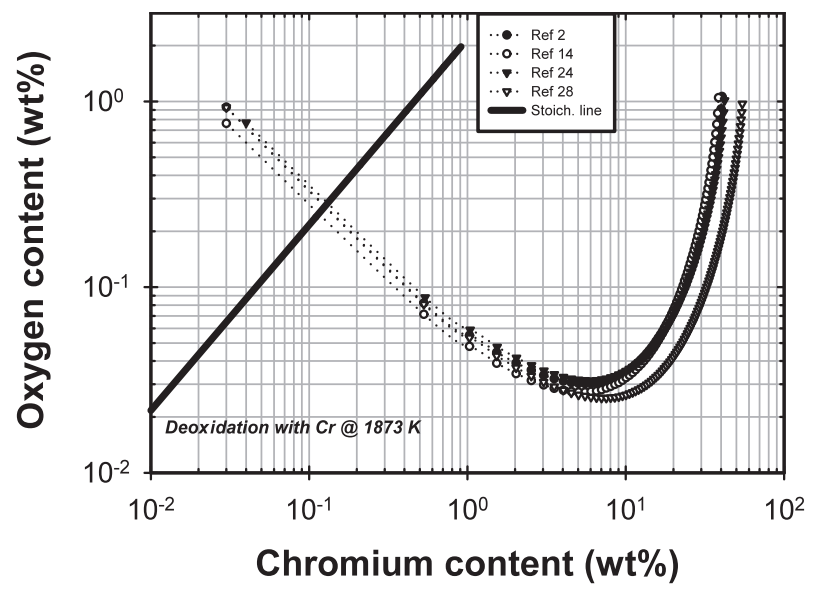

Figure 5. Comparison of equilibria data on steel deoxidation with chromium at $1,873 \mathrm{~K}$.

Figura 5. Comparativo de los datos al equilibrio al desoxidar acero con cromio a $1.873 \mathrm{~K}$.

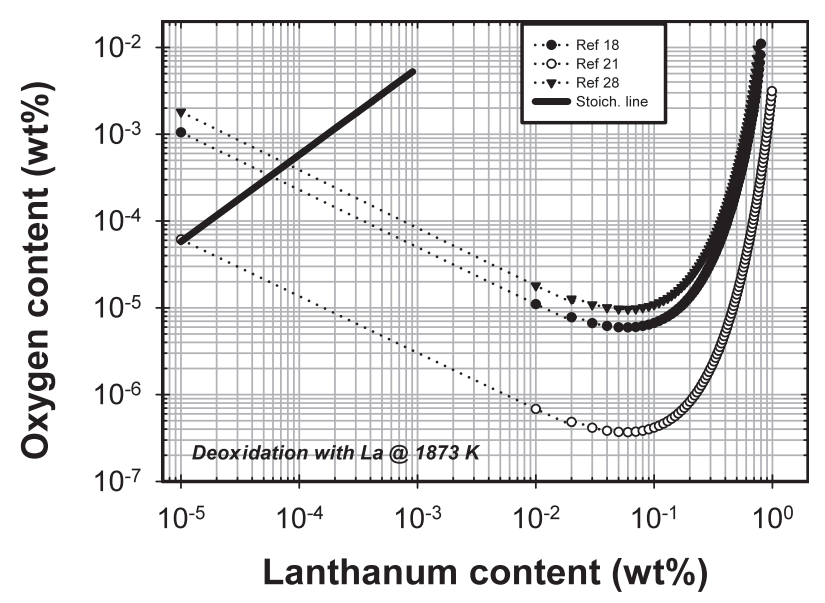

Figure 6. Comparison of equilibria data on steel deoxidation with lanthanum at $1,873 \mathrm{~K}$.

Figura 6. Comparativo de los datos al equilibrio al desoxidar acero con lantano a $1.873 \mathrm{~K}$.

interaction parameters, $\left(\mathrm{e}_{\mathrm{i}}^{\mathrm{J}}\right.$ or $\left.f_{\mathrm{i}}\right)$. As discussed earlier, the former effect (shown as parallelism between Henrian's behaviours) is observed in figures 4 a), 4 b), 6 and 8; while the latter is shown in figures 4 a), $6,7,9,10,11,12$ a) and 12 b).

If deoxidation of iron is considered as one set of equivalent equilibria that are related by the ability of a deoxidizer to react with oxygen, then these critical compositional ratios can be conveniently rearranged, according to their oxidation state. Hence, three major groups of equilibria are considered. These would involve oxides constituted of: bivalent, trivalent or tetravalent deoxidizing elements. Such

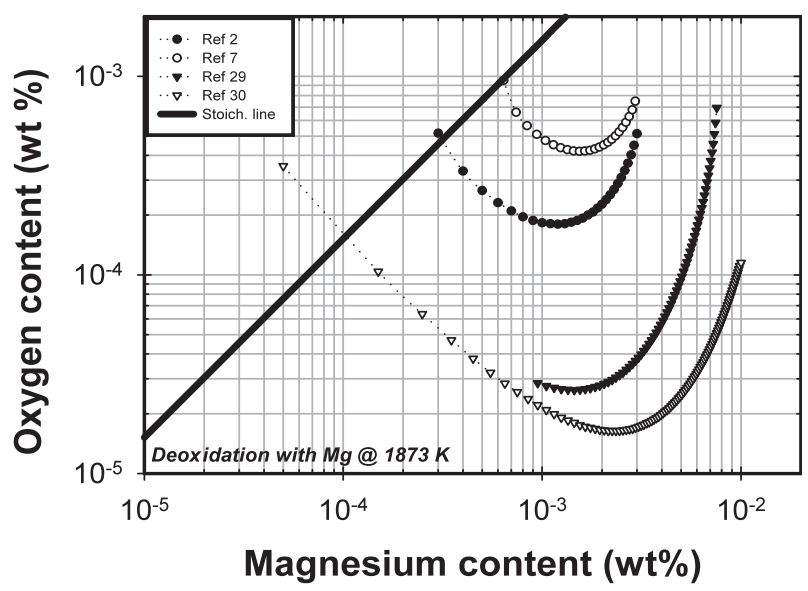

Figure 7. Comparison of equilibria data on steel deoxidation with magnesium at 1,873 K.

Figura 7. Comparativo de los datos al equilibrio al desoxidar acero con magnesio a $1.873 \mathrm{~K}$.

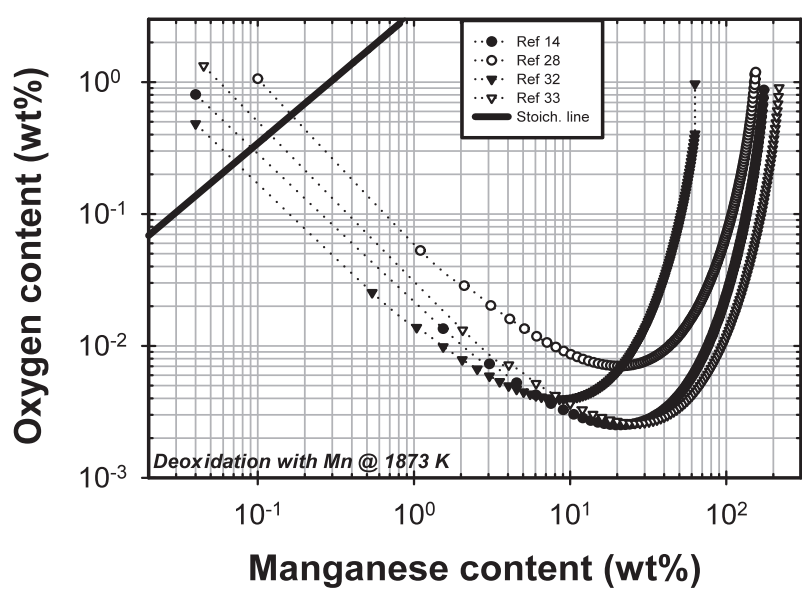

Figure 8. Comparison of equilibria data on steel deoxidation with manganese at $1,873 \mathrm{~K}$.

Figura 8. Comparativo de los datos al equilibrio al desoxidar acero con manganeso a $1.873 \mathrm{~K}$.

set of equilibria plotted as weight percents of deoxidizer vs oxygen on logarithmic scales show that stoichiometric ratios are more congruent among themselves than the ones representing minimum oxygen contents. Such results are shown in figures 13 to 15 .

However; is worth to mention that stoichiometric ratios as expected; show a characteristic slope for each group of data. On the contrary, information related to minimum oxygen contents appear as a wide band of data without regard the valence considered in each group. In fact, the major incongruities are those related to the most stable lanthanide species, i.e. $\mathrm{La} / \mathrm{La}_{2} \mathrm{O}_{3}$ 
TECHNICAL NOTE. ASSESSMENT OF THERMOCHEMICAL DATA ON STEEL DEOXIDATION NOTA TÉCNICA. VALORACIÓN DE DATOS TERMOQUÍMICOS EN LA DESOXIDACIÓN DEL ACERO

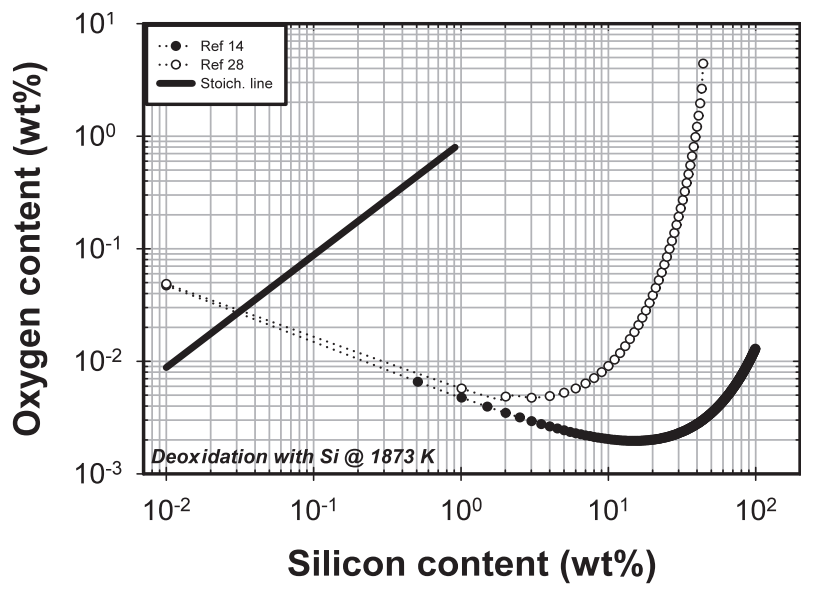

Figure 9. Comparison of equilibria data on steel deoxidation with silicon at $1,873 \mathrm{~K}$.

Figura 9. Comparativo de los datos al equilibrio al desoxidar acero con silicio a $1.873 \mathrm{~K}$.

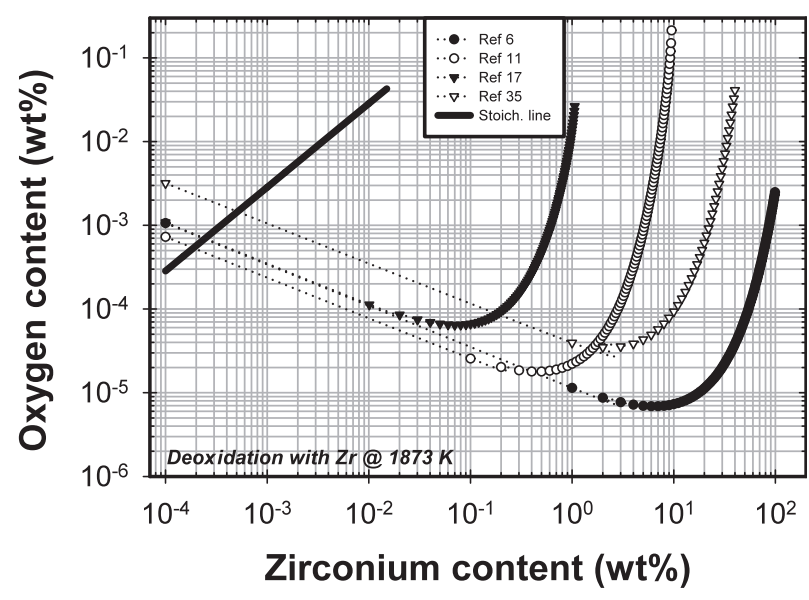

Figure 10. Comparison of equilibria data on steel deoxidation with zirconium at $1,873 \mathrm{~K}$.

Figura 10. Comparativo de los datos al equilibrio al desoxidar acero con zirconio a $1.873 \mathrm{~K}$.

and $\mathrm{Ce} / \mathrm{Ce}_{2} \mathrm{O}_{3}$, see figure 15 . It is also worth noting that in the case of $\mathrm{M}_{2} \mathrm{O}_{3}$ oxides, both the stoichiometric line and the lines defining the minimum oxygen content converge to points that satisfy the condition defined by the difference of electronegativities equal to zero; such convergence is not observed in $\mathrm{MO}_{2}$ nor $\mathrm{MO}$ oxide systems.

A global deoxidation behaviour, which includes most of the deoxidizers is shown in figure 15 . On this figure, both stoichiometric and minimum oxygen contents as bands of data are shown. If the electronegativity concept is applied to a deoxidizer with respect to oxygen to form an oxide, then this periodic potentiality can be used as a guideline to

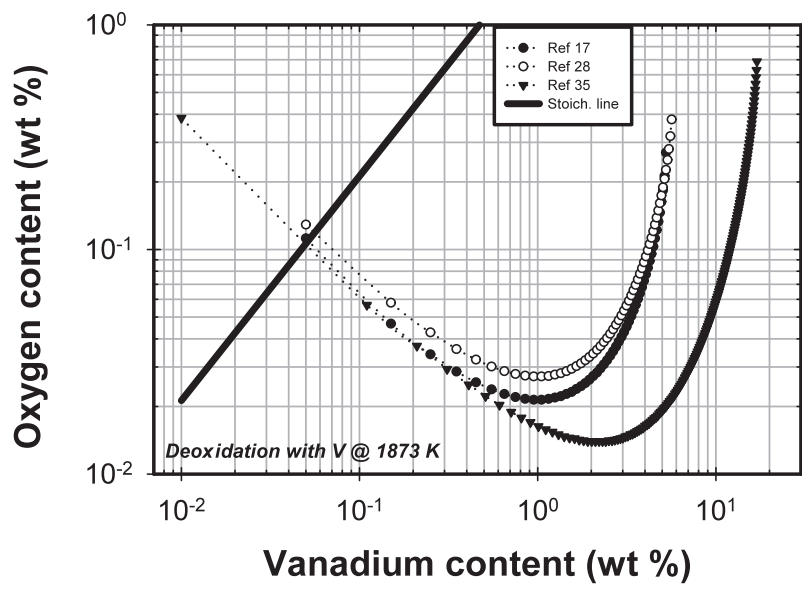

Figure 11. Comparison of equilibria data on steel deoxidation with vanadium at $1,873 \mathrm{~K}$.

Figura 11. Comparativo de los datos al equilibrio al desoxidar acero con vanadio a $1.873 \mathrm{~K}$.

reframe critical composition ratios previously cited. By selecting the most congruent thermochemical data to satisfy this chemical ability, better correlations are found for both stoichiometric and minimum composition ratios. However, it should be pointed out that both sets of critical ratios still manifest themselves as bands of data (Fig. 15). Strictly speaking, electronegativities vs minimum oxygen and stoichiometric ratios are not yet the best way of plotting these data.

If the analysis on thermochemical data is carried out, it can be found that inaccuracies are, as expected, related to chemical factors such as: iron deoxidizing agent and crucible impurities; composition of reaction products and of course a time period to reach actual equilibrium conditions. It is worth mentioning that fewer incongruities are found on deoxidation equilibria of iron melts since the advent of solid electrolyte cells. By using these cells, true oxygen dissolved in iron instead of total oxygen contents is traced. Therefore, provided melts are homogeneous, oxygen contents and temperatures monitored by these cells are determined in situ. It is important to recall that these experimental findings jointly with deoxidizing assays are compelled to satisfy theoretical grounds or vice versa.

On the other hand, despite the fact that most equilibria on deoxidation take into account deviations from the ideal Henrian behaviour, due to interrelated effects among free energies of formation or equilibrium constants and interaction parameters, small changes in them lead to significative variations of those results predicted by equation (14). To bring in a closer assessment on 


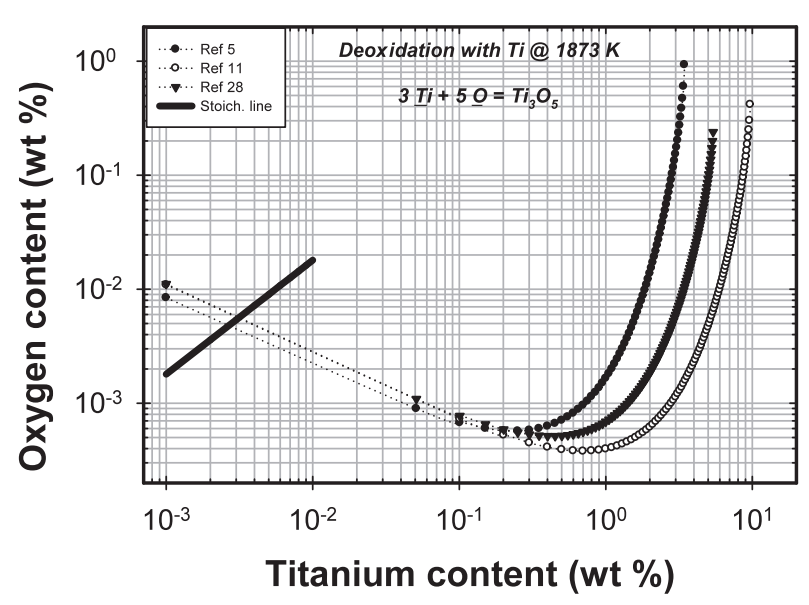

a)

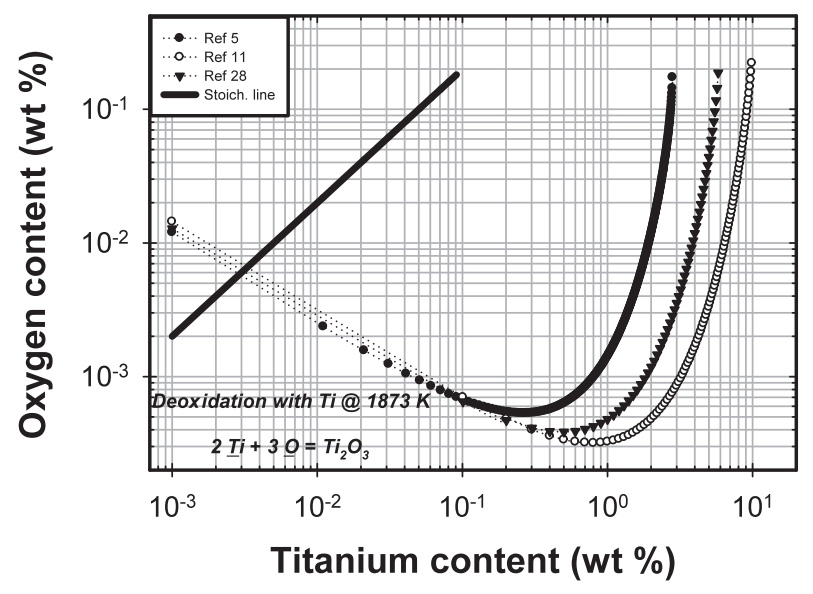

b)

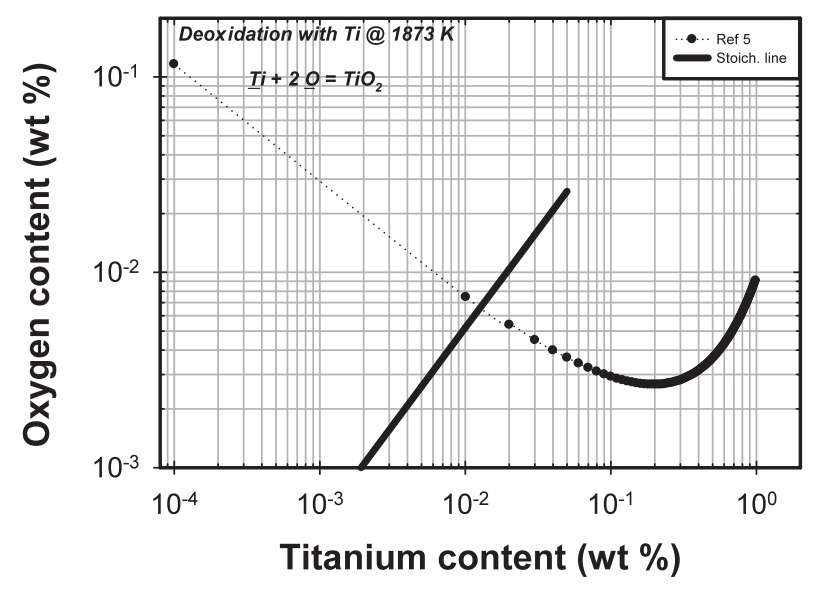

c)

Figure 12. Comparison of equilibria data on steel deoxidation with titanium at $1,873 \mathrm{~K}$. (a) formation of $\mathrm{Ti}_{3} \mathrm{O}_{5}$, (b) formation of $\mathrm{Ti}_{2} \mathrm{O}_{3}$. (c) formation of $\mathrm{TiO}_{2}$.

Figura 12. Comparativo de los datos al equilibrio al desoxidar acero con titanio a $1.873 \mathrm{~K}$. (a) formación de $\mathrm{Ti}_{3} \mathrm{O}_{5}$, (b) formación de $\mathrm{Ti}_{2} \mathrm{O}_{3}$. (c) formación de $\mathrm{TiO}_{2}$.

deviations observed in a real Henrian equilibrium, one can observe that departures from ideality occur at composition ratios driven towards the minimum oxygen content, while at ratios closer to the stoichiometric one, both real and ideal Henrian behaviours have essentially equal ratios. The latter finding indicates to us that a real equilibria represented by composition ratios of oxygen vs. deoxidizer plotted as logarithms show both a lineal and non-lineal behaviours.

Another factor which sensibly induces deviations of composition ratios to unreasonable values of equilibria is that shown by deoxidizing agents with several oxidation states. This is expected since equilibrium conditions may be affected by more than one stable oxide. Among these one can consider $\mathrm{Ce}$ and $\mathrm{Ti}$, where $\mathrm{Ce}_{2} \mathrm{O}_{3}$ and $\mathrm{CeO}_{2}$ and $\mathrm{Ti}_{2} \mathrm{O}_{3}$ and $\mathrm{TiO}_{2}$ may coexist.
By carrying out an analysis on pure chemical basis one can find that the degree of ionic bonding between two atoms is defined from the difference in affinity of the species for electrons. Thus, the larger this difference the stronger will be the tendency for electron exchange. In other words, if the chemical affinity is considered as a measure by which an electron can be removed from an atom to form an ion, such statement should be understood as the definition of electronegativity. Under these principles, Pauling assigned a scale of electronegativities between two elements, which has been used to account for bond enthalpies, percentage of ionic character of the bond and type of oxide (basic or acidic). In this sense, electronegativity has to be defined as the power of an atom to attract electrons by itself when it is combined in a compound. 


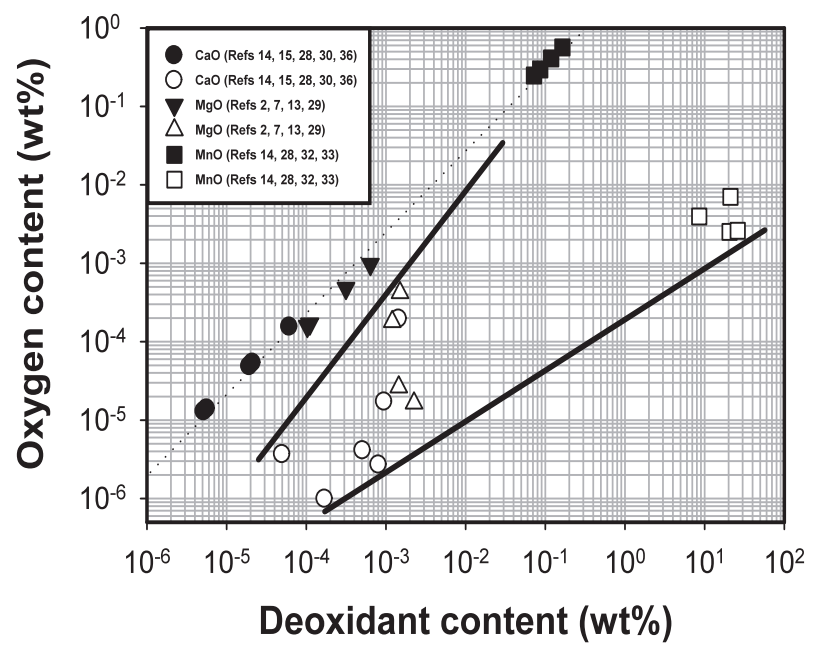

Figure 13. Correlation between stoichiometric and minimum oxygen content point in $\mathrm{MO}$ oxide type at $1,873 \mathrm{~K}$. (Full symbols stoichiometric point, empty symbols minimum oxygen).

Figura 13. Correlación entre el punto estequiométrico y el contenido mínimo de oxígeno en óxidos tipo MO a $1.873 \mathrm{~K}$. (los símbolos llenos representan el punto estequiométrico; los símbolos vacios indican el mínimo contenido de oxígeno).

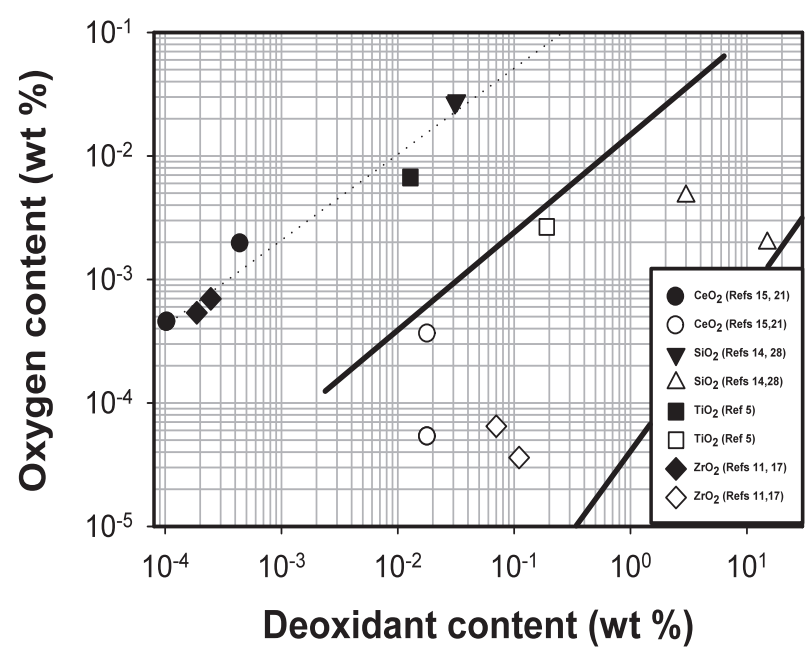

Figure 14. Correlation between stoichiometric and minimum oxygen content point in $\mathrm{MO}_{2}$ oxide type at 1,873 K. (Full symbols stoichiometric point, empty symbols minimum oxygen).

Figura 14. Correlación entre el punto estequiométrico y el contenido mínimo de oxígeno en óxidos tipo $\mathrm{MO}_{2}$ a $1.873 \mathrm{~K}$. (los símbolos llenos representan el punto estequiométrico; los símbolos vacios indican el mínimo contenido de oxígeno).

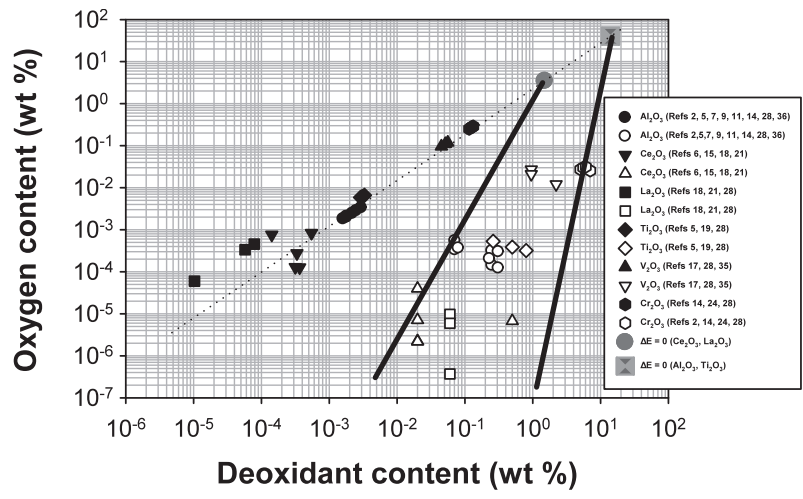

Figure 15. Correlation between stoichiometric and minimum oxygen content point in $\mathrm{M}_{2} \mathrm{O}_{3}$ oxide type at $1,873 \mathrm{~K}$. (Full symbols stoichiometric point, empty symbols minimum oxygen).

Figura 15. Correlación entre el punto estequiométrico y el contenido mínimo de oxígeno en óxidos tipo $\mathrm{M}_{2} \mathrm{O}_{3}$ a $1.873 \mathrm{~K}$. (los símbolos llenos representan el punto estequiométrico; los símbolos vacios indican el mínimo contenido de oxígeno).

\section{CONCLUSIONS}

Thermochemical data has been analyzed and assessed in order to have a better understanding of deoxidation equilibria in a steelmaking melt. Treatment of the data available shows that it is possible to establish a new criterion to account for the ability from any deoxidizer to remove the oxygen dissolved in the melt. This new criterion is based upon the stoichiometric ratio between the de-oxidant element and oxygen. This new criterion allow for simplifying the manner in which data is presented, this; because now depending on the stoichiometric ratio of the oxides in the melt, they can be gathered in a single line instead of a range of composition. This is possible, because instead of attending the deviations from the Henrian behaviour, this approach takes in account the difference in electronegativities between the deoxidizer and oxygen; which tend to converge to a point from where it is possible accommodate equilibrium data as straight lines instead of a range of values.

\section{REFERENCES}

[1] C. Wagner, Thermodynamics of alloys, Ed. Addison-Wesley, New York, U.S.A., 1952, pp. 10-25.

[2] J. Sung-Koo, K. Seon-Hyo, and S. Bo, Metall. Mater. Trans. 33B (2002) 703-709. 
[3] Ghosh A., Secondary Steelmaking, principles and applications, Ed. CRC Press, New York, U.S.A., 2001, pp. 105-146.

[4] K. Suzuki, S. Ban-Ya, and M. Hino, ISIJ Int. 41 (2001) 813-817.

[5] M. Zhongting, Metall. Mater. Trans. 32B (2001) 87-103.

[6] A. Karasev and H. Suito, Metall. Mater. Trans. 30B (1999) 249-257.

[7] H. Itoh, M. Hino and S. Ban-Ya, Metall. Mater. Trans. 28B (1997) 953-956.

[8] H. Ohta and H. Suito, Metall. Mater. Trans. 27B (1996) 943-953.

[9] S. Dimitrov, A. Weyl and D. Janke, Steel Res. Intl. 66 (1995) 3-7.

[10] E.T. Turkdogan, Physical chemistry of high temperature technology, Ed. Academic Press, New York, U.S.A., 1980, pp. 150-226.

[11] D. Janke and W.A. Fischer, Archiv. Für das Eisenhüttenwesen 47 (1976) 195-198.

[12] K. Taguchi, H. Ono-Nakazato, D. Nakai, T. Usui and K. Marukawa, ISIJ Int. 43 (2003) 1705-1709.

[13] R. Inoue and H. Suito, Steel Res. Intl. 65 (1994) 403-409.

[14] Japan Society for Promotion of Science, Steelmaking data sourcebook, Ed. Gordon \& Breach Science Publishers, New York, U.S.A., 1988, pp. 1-271.

[15] Q. Han, X. Zhang, D. Chen and P. Wang, Met. Trans. B 19 (1988) 617-622.

[16] Q. Han, X. Feng, S. Liu, H. Niu and Z. Tang, Met. Trans. B 21 (1990) 295-302.

[17] C.H.P. Lupis, Chemical Thermodynamics of Materials, Ed. North Holland, New York, U.S.A., 1983, pp. 235-262.

[18] E.T. Turkdogan, Archiv. Für das Eisenhüttenwesen 54 (1983) 1-10.

[19] D. Janke and W.A. Fischer, Archiv. Für das Eisenhüttenwesen 49 (1978) 425-430.
[20] A. Vahed and D.A.R. Kay, Met. Trans. B 7 (1976) 375-383.

[21] W.G. Wilson, D.A.R. Kay and A. Vahed, JOM 26 (1974) 14-23.

[22] G. Kinne, A.F. Vishkarev and V.I. Yavoiski, Vyssh. Uchebn. Zaved, Chem. Metall. (1963) 65.

[23] M. Tanahashi, N. Furuta, T. Taniguchi, C. Yamauchi and T. Fujisawa, ISIJ Int. 43 (2003) 7-13.

[24] S. Dimitrov, H. Wenz, K. Koch and D. Janke, Steel Res., 66 (1995) 39-44.

[25] J. Geldenhuis and R. Dippenaar, Met Trans B, (1991) 915-918.

[26] M. Heinz, K. Koch and D. Janke, Steel Res. 60 (1989) 246-254

[27] C.K. Kim and A. McLean, Met. Trans. B, 10 (1979) 585-594.

[28] G.K. Sigworth and J.F. Elliot, Met. Sci. J. 8 (1974) 298-310.

[29] H. Ohta and H. Suito, Met. Trans. B 28 (1997) 1131-1139.

[30] R. Inoue and H Suito, Met. Trans. B 25 (1994) 235-244.

[31] V.Y. Dashevskii, A.M. Katsnelson, N.N. Makarova, K.V. Grigorovitch and V.I. Kashin, ISIJ Intl. 43 (2003) 1487-1494.

[32] S.B. Lee, S.M. Jung, H.G. Lee and C.H. Rhee, Metall. Mater. Trans. B 33 (2002) 930-932.

[33] S. Dimitrov, A. Weyl and D. Janke, Steel Res. 66 (1995) 87-92.

[34] F. Oeters, Metallurgie der Stahlherstellung, Ed. Springer-Verlag, Germany, 1989, pp. 51117.

[35] C. Bodsworth and H.B. Bell, Physical chemistry of iron and steel manufacture, Ed. Longman, London, U.K., 1972, pp. 169-300

[36] Japan Society for Promotion of Science, Steelmaking data sourcebook, Ed. Gordon \& Breach Science Publishers, New York, U.S.A., 1988, pp. 273-312. 